\title{
The water intake of ewes
}

\author{
BY J. M. FORBES \\ Department of Agriculture, University of Leeds \\ (Received I3 March I967-Accepted I4 August 1967)
}

\begin{abstract}
I. Two experiments were carried out with non-pregnant ewes in which individual drymatter intake (DMI) and total water intake ('TWI) were measured. TWI was closely correlated with DMI; TWI/unit DMI was higher for silage than for cubed dried grass and with both foods water intakes were higher than with long hay.

2. Twelve ewes were fed on silage and twelve on hay from the gth to the 19 th week of pregnancy. TWI/unit DMI of each feed doubled during this period. Another twenty-four ewes were fed on silage from the $14^{\text {th }}$ to the 20 th week of pregnancy. TWI/unit DMI was positively related to litter size.

3. Fifteen ewes were fed on hay from the $4^{\text {th }}$ week of pregnancy until the 7 th week of lactation. Milk yield was estimated weekly. Six non-pregnant ewes were controls. TWI/unit DMI for the seven twin-bearing and the nine single-bearing ewes in the last 4 and 3 weeks of pregnancy respectively was significantly higher than that of the six non-pregnant ewes. In the control group TWI/unit DMI was closely related to environmental temperature. In the first 4 weeks of lactation TWI/unit DMI was greater than the sum of TWI/unit DMI of the non-pregnant ewes plus the water in the milk.

4. The results supplement those used by the Agricultural Research Council (1965) to assess the water requirements of sheep.
\end{abstract}

The water balance of farm animals, including sheep, has been reviewed by Leitch \& Thomson (1944), and more recently the Agricultural Research Council (1965) has estimated the water requirements of sheep and cattle. The water intake of pregnant ewes has been measured by Head (I953).

With modern methods of sheep management involving housing for part of the year, it is necessary to estimate the water requirements of sheep in various physiological conditions. Five experiments are described in which the water intake of non-pregnant, pregnant and lactating ewes is reported. The results demonstrate the effects of drymatter intake, environmental temperature, advancing pregnancy and lactation on water intake.

\section{EXPERIMENTAL}

\section{Non-pregnant ewes}

Expt $\mathrm{I}$. Seven non-pregnant Scottish Halfbred (Border Leicester $\times$ Cheviot) ewes of about $100 \mathrm{~kg}$ live weight were fed on silage $\left(\mathrm{pH}_{4} \cdot 9\right)$ made from wilted grass from 2 November 1964 to 18 December 1964 (four ewes) or I January 1965 (three ewes).

Expt 2. Two non-pregnant Specklefaced Welsh ewes of $50 \mathrm{~kg}$ live weight were fed on long hay and two on ground, cubed dried grass from 22 June to 22 August 1965. The diets were then reversed and given for a further 6 weeks. 


\section{Pregnant ewes}

Expt 3. Twenty-four Scottish Halfbred ewes were mated with Suffolk rams in October 1963 . Twelve were fed on hay and twelve on grass silage from the gth to the I 9 th week of pregnancy. From the $\mathrm{I} 2$ th week of pregnancy $\mathrm{I}$ lb of crushed oats was given per head daily.

Expt 4. Silage from the same source as in Expt I was fed to twelve Scottish Halfbred and twelve Specklefaced Welsh ewes mated with Suffolk rams in October I964, from the $14^{\text {th }}$ week of pregnancy until a week before lambing was due.

\section{Non-pregnant, pregnant, and lactating ewes}

Expt 5. Fifteen Specklefaced Welsh ewes mated with Suffolk rams during a period of 3 days in October 1965 were fed on hay from the $4^{\text {th }}$ week of pregnancy until the $7^{\text {th }}$ week of lactation. Six non-pregnant ewes acted as controls until the pregnant ewes lambed.

\section{Management}

In each experiment the ewes were individually penned for the whole of the period during which feed and water intakes were being measured. The pens were made with wooden hurdles; each was $7 \mathrm{ft}$ by $3 \mathrm{ft}$ with a feeding rack and trough at one end and a polythene water bucket in a metal bucket holder at the other. The floor was constructed of wooden slats, raised $2 \mathrm{ft}$ above ground level. The pens were situated in a Dutch barn open on the south side.

\section{Table I. Composition of feeds}

\begin{tabular}{|c|c|c|c|c|c|}
\hline $\begin{array}{c}\text { Expt } \\
\text { no. }\end{array}$ & Feed & $\begin{array}{c}\mathrm{DM} \\
\text { content }\end{array}$ & $\begin{array}{c}\text { Crude } \\
\text { protein } \\
\text { content } \\
\text { of DM } \\
(\%)\end{array}$ & $\begin{array}{c}\text { Crude } \\
\text { fibre } \\
\text { content } \\
\text { of DM } \\
(\%)\end{array}$ & $\begin{array}{c}\text { Ash } \\
\text { content } \\
\text { of DM } \\
(\%)\end{array}$ \\
\hline $\mathrm{I}$ and 4 & Silage & 30.9 & 16.7 & 30.2 & II'3 \\
\hline 2 & $\begin{array}{l}\text { Hay } \\
\text { Cubes }\end{array}$ & $\begin{array}{l}85.9 \\
87.0\end{array}$ & $\begin{array}{r}7 \cdot 4 \\
18.8\end{array}$ & $\begin{array}{l}29 \cdot 7 \\
25 \cdot 7\end{array}$ & $\begin{array}{r}5 \cdot 8 \\
\text { I } 1 \cdot 8\end{array}$ \\
\hline 3 & $\begin{array}{l}\text { Silage } \\
\text { Hay }\end{array}$ & $\begin{array}{l}2 \mathrm{I} \cdot \mathrm{I} \\
9 \mathrm{I} \cdot 0\end{array}$ & $\begin{array}{l}13.6 \\
11 \cdot 0\end{array}$ & $\begin{array}{l}3 I^{\prime} \cdot 3 \\
35 \cdot 0\end{array}$ & $\begin{array}{r}22 \cdot 2 \\
7 \cdot 5\end{array}$ \\
\hline 5 & Hay & 86.6 & 10.6 & $37 \cdot \mathbf{I}$ & $6 \cdot 3$ \\
\hline
\end{tabular}

Feed intake was measured daily in Expts 2 and 3 and on 5 days each week in the other experiments. The ewes were always offered at least $20 \%$ more than they would eat; refused food was weighed each morning before the fresh feed was given. Mean weekly dry-matter intakes were calculated. Samples of the feeds were taken at regular intervals for the determination of dry-matter content by drying at $95^{\circ}$ for $24 \mathrm{~h}$. Portions were analysed for crude protein and crude fibre content. The composition of the feeds is shown in Table $I$.

Water intake was measured every morning by adding water to each bucket from a calibrated vessel until the levels reached a predetermined mark on the side of the 
bucket. The buckets were cleaned out and filled with fresh water weekly or whenever they became fouled. When the water was frozen the ice was broken up several times a day. Mean weekly water intake was calculated. To this was added the weight of water estimated to have been taken in with the feed; the value obtained will be called total water intake.

A mineral brick (Boots Pure Drug Co.) was placed in each pen. In Expt 3 this was weighed at the start and end of the experiment.

The means of the daily maximum and minimum temperatures taken at the weather station $400 \mathrm{~m}$ from the Dutch barn were calculated each week. In a previous experiment this temperature was found to be not more than $2^{\circ}$ different from the temperature in the barn.

In Expt 5 milk yield was estimated weekly by separating the lambs from the ewes and allowing them to suck for six brief periods during the $24 \mathrm{~h}$ period of estimation. The lambs were weighed on a spring balance to the nearest $0.5 \mathrm{oz}$ immediately before and after sucking. The difference between the lamb weights before and after sucking was taken as the milk yield.

\section{RESULTS}

\section{Non-pregnant ewes}

Fig. I shows mean total water intake plotted against mean dry-matter intake for each ewe in each week of Expts $I$ and 2. The mean results for the whole of Expt $I$ for the seven ewes are represented by the equation:

$$
\begin{gathered}
\text { TWI }=3.86( \pm 0.75) \text { DMI }-0.99 \\
\text { (residual standard deviation }(\mathrm{RSD})=0.4 \mathrm{I}),
\end{gathered}
$$

where TWI was total water intake and DMI was dry-matter intake, both expressed as $\mathrm{kg}$ per head per day.

The results for each ewe in each week of Expt 2 were similarly plotted (Fig. I) and the lines of best fit were calculated:

$$
\begin{array}{ll}
\text { (cubes) } & \text { TWI }=\mathrm{I} \cdot 55 \mathrm{DMI}+0.75, \\
\text { (hay) } & \mathrm{TWI}=0 \cdot 32 \mathrm{DMI}+\mathrm{I} \cdot 49 .
\end{array}
$$

The intercepts were significantly greater than zero. Results will subsequently be expressed in terms of $\mathrm{kg}$ total water intake per $\mathrm{kg}$ dry-matter intake so as to exclude as far as possible the effect of dry-matter intake on the relationship between other factors and total water intake.

The total water intakes per unit dry-matter intake for the ewes in Expt 2 when fed on cubes or hay were compared by analysis of variance (Snedecor, 1956). Water intake was significantly greater $(P<0.001)$ when the ewes were fed on cubed dried grass (2. $19 \mathrm{~kg}$ water $/ \mathrm{kg}$ dry matter compared with $1.62 \mathrm{~kg} ;$ SE of difference, $\pm 0.1 \mathrm{I})$. There was no significant difference between the dry-matter intakes of the sheep on the two rations.

In Expt 3 the mean intake of mineral lick was significantly greater in the silage-fed group than in that fed on hay (8.5 \pm 0.88 as compared with $5.7 \pm 0.40 \mathrm{~g} /$ head daily). The ewes fed on silage were already eating more ash in their roughage than were those on hay; the total ash intake of the former ewes was therefore considerably greater than that of the latter. 
There was no significant relationship between the weekly mean of total water intake per unit dry-matter intake and weekly mean environmental temperature in Expts I and 2. The overall mean temperatures were $4.0^{\circ}$ and $13.2^{\circ}$ respectively.

In Expt 5, however, there was a significant relationship in the results for the nonpregnant ewes when the mean temperature was higher than $\mathrm{I}^{\circ}$ :

$$
\text { TWI } / D M I=0 \cdot 18( \pm 0 \cdot 03) T+1 \cdot 25 \quad(\mathrm{RSD}=0 \cdot 19),
$$

where TWI/DMI was the mean total water intake per unit dry-matter intake $(\mathrm{kg} / \mathrm{kg})$

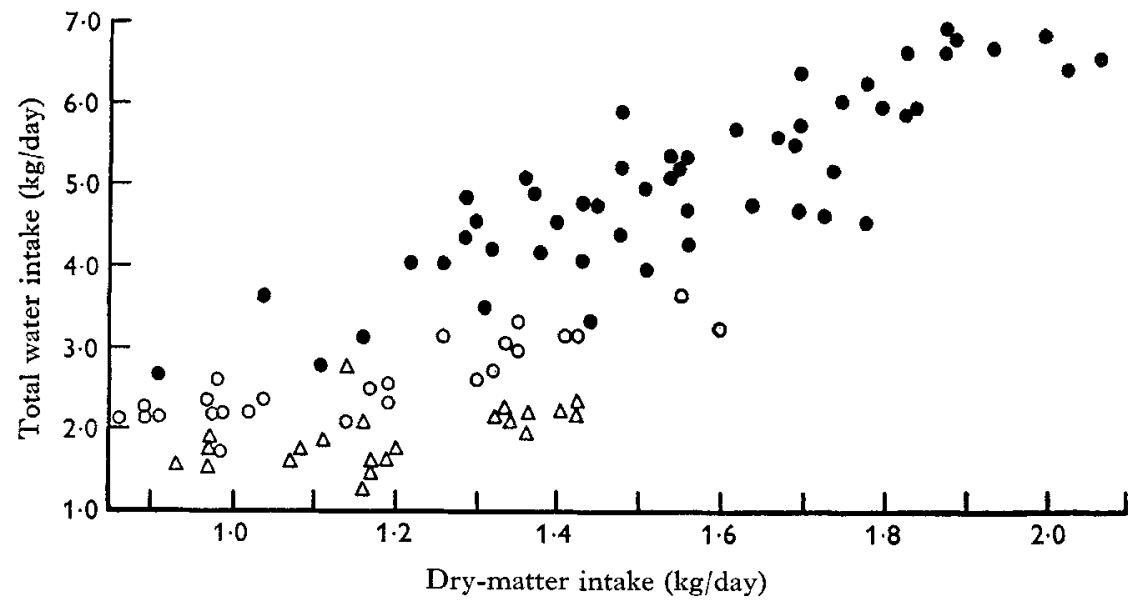

Fig. r. Relationship between total water intake and dry-matter intake in non-pregnant ewes fed on silage (Expt I), cubed dried grass or long hay (Expt 2). S, Scottish Halfbred ewes fed on silage; $O$, Specklefaced Welsh ewes fed on cubed dried grass; $\triangle$, Specklefaced Welsh ewes fed on long hay.

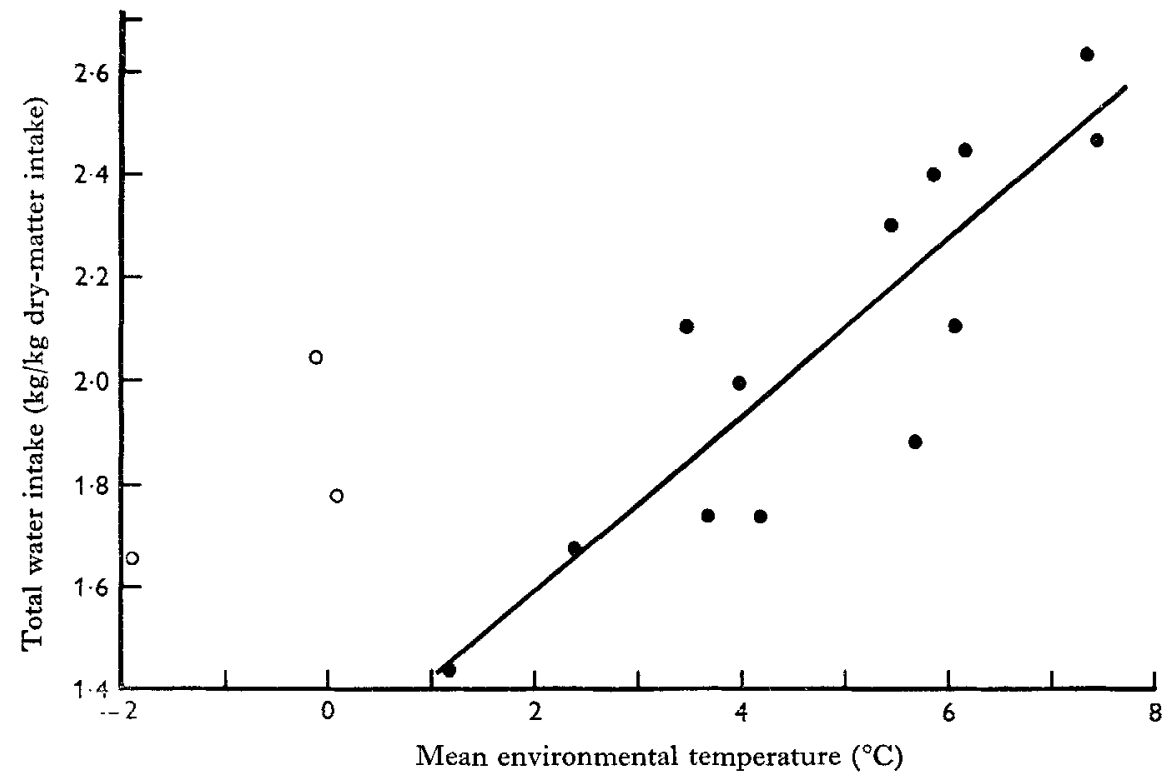

Fig. 2. Effect of environmental temperature on total water intake of the non-pregnant ewes in Expt 5. - values used in calculating equation (4); $O$, values not used in equation (4). Regression line represents equation (4). 
for six ewes and $T$ was the mean of the daily maximum and minimum temperatures for each week. The values for the 3 weeks when the mean environmental temperature was below $I^{\circ}$ do not appear to conform to this relationship (Fig. 2).

\section{Pregnant ewes}

The water intakes for the ewes fed on silage and those fed on hay in Expt 3 are shown in the upper part of Fig. 3. There was no significant difference within diet between ewes bearing single, twin or triplet lambs at any stage.

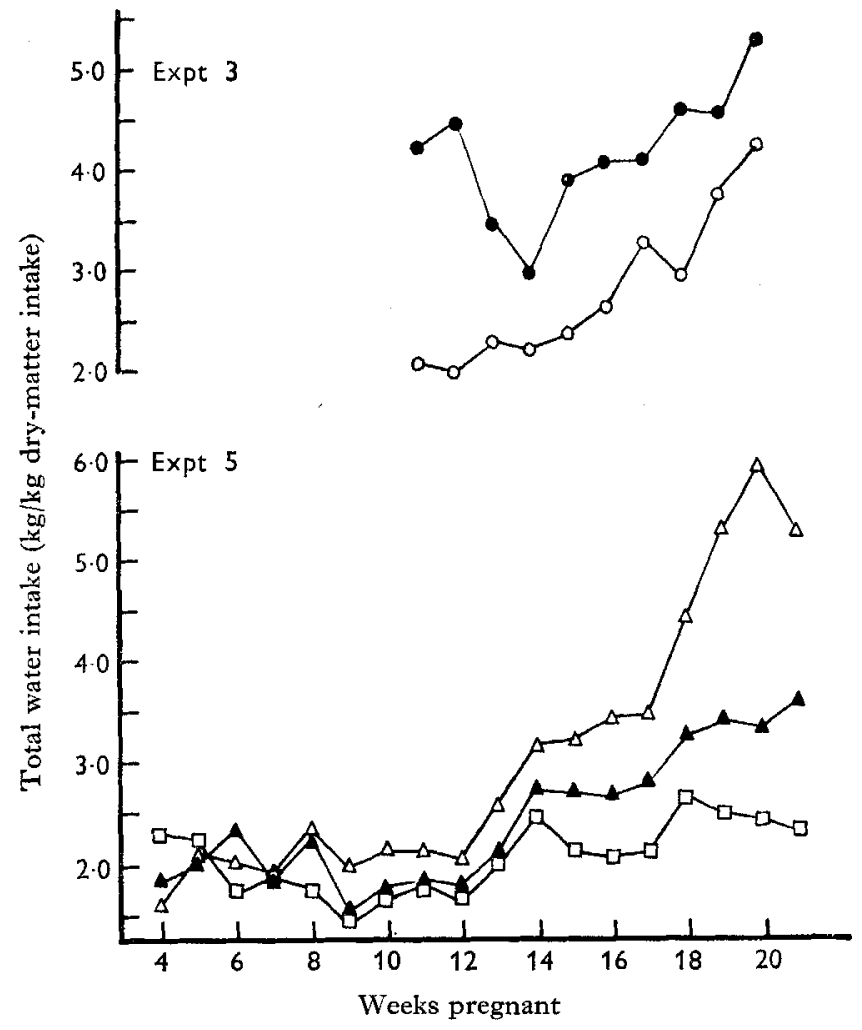

Fig. 3. Total water intakes of pregnant ewes fed on hay or silage (Expt 3) and of ewes not pregnant or carrying one or two lambs (Expt 5). $\bigcirc$, twelve ewes fed on hay; 9 , twelve ewes fed on silage; $\triangle$, six ewes carrying twins; $\Delta$, nine ewes carrying singles; $\square$, six non-pregnant ewes.

Table 2. Mean dry-matter intake (DMI), total water intake (TWI) and TWI/unit $D M I$ of ewes in Expt 4 between 14 and 20 weeks of pregnancy, according to litter size

$\begin{array}{cccccc}\text { Litter } & \begin{array}{c}\text { Number } \\ \text { of ewes }\end{array} & \begin{array}{c}\text { DMI } \\ \text { (kg/day) }\end{array} & \begin{array}{c}\text { TWI } \\ \text { (kg/day) }\end{array} & \begin{array}{c}\text { TWI } / \text { unit } \\ \text { DMI }(\mathrm{kg} / \mathrm{kg})\end{array}\end{array}$

Scottish Halfbred

Specklefaced Welsh size

of ewes

$$
\begin{aligned}
& 5 \cdot 95 \\
& 5.58 \pm 0.4 x^{*} \\
& 6 \cdot 6 x \\
& 2 \cdot 22 \pm 0.3 x^{*} \\
& 2 \cdot 60 \pm 0.27^{*}
\end{aligned}
$$$$
0.83 \pm 0.10^{*}
$$

$3 \cdot 10$ $3 \cdot 69$ $4 \cdot 63$ $2 \cdot 68$ $3 \cdot 52$

* Mean values with their standard errors. 
In the first few weeks of the experiment the ewes fed on silage drank little free water. The ewes fed on hay drank large quantities of water throughout the experiment; even so the total water intake per unit dry-matter intake was higher in the silage-fed ewes.

Table 2 gives the water and dry-matter intakes of the ewes of the two breeds in Expt 4 according to litter size. The ratio of total water intake to dry-matter intake increased with litter size but the differences were not significant.

The lower part of Fig. 3 shows the total water intake per unit dry-matter intake in Expt 5 for the three classes of ewe from the $4^{\text {th }}$ to 2 ist weeks of pregnancy. For the ewes carrying twin lambs the ratio was significantly higher than that for the nonpregnant ewes in the 16 th, 18 th, 19 th, 20 th and 21 st weeks of pregnancy but was at no time significantly greater than that for the single-bearing ewes. The ewes with one foetus took in significantly more water per unit dry-matter in the I6th, Igth, 2oth and 2ist weeks of pregnancy than did the non-pregnant ewes.

Table 3. Water intakes of single- and twin-bearing ewes in Expt 5 during the last 3 months of pregnancy compared with those of non-pregnant ewes

\begin{tabular}{|c|c|c|c|c|c|}
\hline \multirow[b]{2}{*}{$\begin{array}{l}\text { Months } \\
\text { pregnant }\end{array}$} & \multirow[b]{2}{*}{$\begin{array}{c}\text { Non-pregnant } \\
\text { TWI/DMI } \\
\text { (kg/kg) }\end{array}$} & \multicolumn{2}{|c|}{ Single-bearing } & \multicolumn{2}{|c|}{ Twin-bearing } \\
\hline & & $\begin{array}{c}\text { TWI/DMI } \\
(\mathrm{kg} / \mathrm{kg})\end{array}$ & $\begin{array}{c}\text { As } \% \\
\text { value for } \\
\text { non-pregnant } \\
\text { ewes }\end{array}$ & $\begin{array}{c}\text { TWI/DMI } \\
(\mathrm{kg} / \mathrm{kg})\end{array}$ & $\begin{array}{c}\text { As \% } \\
\text { value for } \\
\text { non-pregnant } \\
\text { ewes }\end{array}$ \\
\hline 3 & $\mathbf{I} \cdot 78$ & $1 \cdot 88$ & 106 & $2 \cdot 22$ & 125 \\
\hline 4 & $2 \cdot 18$ & $2 \cdot 73$ & 125 & $3 \cdot 3^{2}$ & 152 \\
\hline 5 & $2 \cdot 46$ & $3 \cdot 39$ & I 38 & $5 \cdot 23$ & 212 \\
\hline
\end{tabular}

DMI, dry-matter intake; TWI total water intake.

The mean water intakes for the three groups of ewes for the 3 rd, $4^{\text {th }}$ and 5 th months of pregnancy are given in Table 3 . It will be seen that in this experiment the increase in water intake per unit of dry-matter intake in the twin-bearing ewes was more than double that in the single-bearing ewes. The mean dry-matter intake of the former ewes was, however, lower than that of the ewes carrying singles, so that the difference in free water intake was not as great as the difference in total water intake per unit drymatter intake.

In view of the effect of litter size on water intake it might be expected that litter weight in the last few weeks of pregnancy, as estimated by litter birth weight, would affect the weight of water taken in during late pregnancy. The mean total water intake per unit dry-matter intake for each pregnant ewe over the last 6 weeks of Expts 3-5 was therefore related to litter birth weight by linear regression analysis:

$$
\begin{array}{ll}
\text { Expt 3 } & \text { TWI/DMI }=0.01 \quad( \pm 0.08) B+3.36 \quad(\mathrm{RSD}=1.28), \\
\text { Expt 4 } & \text { TWI/DMI }=0.17( \pm 0.09) B+2.10 \quad(\mathrm{RSD}=\mathrm{I} \cdot 04), \\
\text { Expt 5 } & \text { TWI/DMI }=-0.02( \pm 0.17) B+3.62 \quad(\mathrm{RSD}=0.85),
\end{array}
$$

where TWI/DMI was the total water intake per unit dry-matter intake $(\mathrm{kg} / \mathrm{kg})$ and $B$ was the total litter birth weight $(\mathrm{kg})$. In each equation the slope of the line was nonsignificant. Litter weight therefore had little effect on water intake in late pregnancy when examined over the whole range of birth weights. 


\section{Lactating ewes}

There were no significant differences in milk yield, dry-matter intake or total water intake between the eleven ewes that reared singles and the four with twins in Expt 5 . The mean values of water intake for all fifteen ewes are given in Table 4 and are compared with the water intake of non-pregnant ewes calculated from equation (4). The last two columns of Table 4 express water intake as a proportion of dry-matter intake, after subtracting the weight of water in the milk from the total water intake; these columns are therefore 'corrected' for milk yield. The fact that the last column contains figures greater than roo shows that lactation stimulates water intake to a greater extent than can be accounted for solely by the water in the milk.

Table 4. Water intake of lactating ewes in Expt 5

\begin{tabular}{|c|c|c|c|c|c|}
\hline \multirow{3}{*}{\multicolumn{2}{|c|}{ Non-lactating ewes }} & \multicolumn{4}{|c|}{ Lactating ewes } \\
\hline & & \multicolumn{2}{|c|}{ Actual intake } & \multicolumn{2}{|c|}{$\begin{array}{l}\text { Intake corrected to } \\
\text { allow for water in milk }\end{array}$} \\
\hline & & \multirow[b]{2}{*}{$\begin{array}{c}\text { TWI/DMI } \\
(\mathrm{kg} / \mathrm{kg})^{*}\end{array}$} & \multirow{2}{*}{$\begin{array}{c}\text { As } \% \text { of } \\
\text { value for } \\
\text { non-lactating } \\
\text { ewes }\end{array}$} & \multirow[b]{2}{*}{$\begin{array}{l}\text { (TWI-MW)/ } \\
\text { DMI }(\mathrm{kg} / \mathrm{kg})\end{array}$} & \multirow{2}{*}{$\begin{array}{c}\text { As } \% \text { of } \\
\text { value for } \\
\text { non-lactating } \\
\text { ewes }\end{array}$} \\
\hline $\begin{array}{l}\text { TWI/DMI } \\
(\mathrm{kg} / \mathrm{kg})\end{array}$ & $\begin{array}{l}\text { Week of } \\
\text { lactation }\end{array}$ & & & & \\
\hline $2 \cdot 23$ & I & $3.90 \pm 0.34$ & $\mathrm{r} 75$ & - & - \\
\hline 2.05 & 2 & $4.20 \pm 0.25$ & 205 & $3 \cdot 04$ & 148 \\
\hline$x \cdot 94$ & 3 & $4.4 I \pm 0.21$ & 227 & $3 \cdot 19$ & 164 \\
\hline $2 \cdot 14$ & 4 & $3.71 \pm 0.25$ & 173 & $2 \cdot 77$ & 129 \\
\hline $2 \cdot 61$ & 5 & $3.69 \pm 0.22$ & 141 & $2 \cdot 58$ & 99 \\
\hline $2 \cdot 70$ & 6 & $3.40 \pm 0.33$ & 126 & $2 \cdot 80$ & 104 \\
\hline $2 \cdot 52$ & 7 & $3 \cdot 51 \pm 0^{\prime} 33$ & I 39 & $2 \cdot 90$ & II5 \\
\hline
\end{tabular}

DMI dry-matter intake; TWI total water intake; MW water in milk.

* Mean for fifteen ewes with standard error.

\section{DISCUSSION}

It has been assumed by other workers that the measured voluntary intake of water by an animal is an indication of its water requirements. Bott, Denton \& Weller (1965) have shown that sheep are able to adjust water intake to meet a water deficit imposed upon them. It seems unlikely, therefore, that sheep would indulge in luxury intake of water, or would drink less than their requirements. The assumption that water intake reflects water requirements has therefore been made in this work also.

In Expt 2 the intercepts of the regression lines on the total water intake axis are positive and significantly different from zero. This is accounted for by the fact that starved animals still require water to replace that lost by evaporation and in the urine. It can be estimated that a sheep of average weight would lose about $0.5 \mathrm{~kg}$ of water per day by vaporization and about $\mathrm{I} \mathrm{kg}$ per day in the urine (Blaxter, Graham, Wainman \& Armstrong, I959), giving a total requirement of $\mathrm{I} \cdot 5 \mathrm{~kg}$. This is very close to the intercept of equation (3) for hay-fed sheep. The estimate of the fasting water intake of the ewes when fed on the cubed dried grass was only $0.75 \mathrm{~kg}$ (equation (2)), water intake being affected to a greater extent by dry-matter intake $(\mathrm{I} \cdot 55 \mathrm{~kg} / \mathrm{kg}$ 
dry matter, as compared with $0.32 \mathrm{~kg} / \mathrm{kg}$ dry matter when fed on long hay). The ash content of the dried grass was much higher than that of the hay and this would explain the higher water intake of the ewes when fed on the dried grass cubes if about half of the extra ash was soluble and therefore likely to affect water intake (Wilson, I966). Also the higher protein content of the dried grass might stimulate a higher intake of water (Sykes, 1955) due to the greater volume of urine produced by the kidneys in excreting the higher quantity of nitrogenous waste products.

The negative intercept in equation I obtained from the results of Expt I cannot be explained by the arguments used above. It is inconceivable that if a ewe from Expt I had been starved then it would have drunk a negative amount of water. It must be assumed therefore that at lower dry-matter intakes than those encountered in Expt I the slope of total water intake against dry-matter intake would be less steep.

These results agree with the close relationship between total water intake and drymatter intake shown by both ruminants (Winchester \& Morris, 1956; Calder, Nicholson \& Cunningham, 1964) and non-ruminants (Cizek, 1959). This effect can be partly explained by the increased amount of water lost to the body via the faeces at a higher level of feed intake and by the increase in metabolism associated with a higher feed intake, followed by the need to excrete more waste products via the kidney. Blaxter et al. (1959) found that at $8^{\circ}$ an increase in the weight of dry matter fed from I.2 to $\mathrm{I} \cdot 8 \mathrm{~kg} / \mathrm{head}$ per day caused an increase in water loss of about $0.5 \mathrm{~kg} / \mathrm{day}$ in the faeces and $0.5 \mathrm{~kg} /$ day in the urine. An increase in intake of $\mathrm{I} \mathrm{kg} /$ day would therefore be expected to cause an increase of $\mathrm{I} \cdot 7 \mathrm{~kg}$ in the daily loss of water in faeces and urine. This figure is not much greater than the slope of equation (2), but is not comparable with those of equations ( $\mathrm{I}$ ) or (3). The relationship between total water intake and dry-matter intake in Expts $\mathrm{I}$ and 2 does not, therefore, agree wholly with the results of Blaxter et al. (1959) in both slope and intercept. It must be emphasized, however, that their sheep were freshly clipped, fed on a different diet at restricted levels of feeding, and under more controlled conditions than were our sheep.

The mean water intake per unit of dry-matter intake was generally higher in ewes fed on silage than in those fed on hay. In Expt 3 pregnant ewes took in more water per unit of silage dry matter than they did per unit of hay dry matter. This result was similar to that of Calder et al. (1964). The ash content of the silage used in Expt 3 was almost three times that of the hay. If part of this difference was soluble ash then it would stimulate water intake (Wilson, 1966). In addition, the ewes fed on silage consumed more mineral lick than those on hay, thus boosting the soluble ash intake even further. Another possibility is that sheep drink more water when fed on silage in order to raise the $\mathrm{pH}$ of this feed by dilution (Harris \& Wilson, 1964 ).

The relationship between total water intake and mean environmental temperature above $\mathrm{I}^{\circ}$ is shown in equation (4) for the non-pregnant ewes of Expt 5 . It is surprising that there is such a great increase in water intake $(\mathrm{I} \cdot 2 \mathrm{~kg} / \mathrm{kg}$ dry-matter $)$ for an increase in temperature of only $7^{\circ}$. According to Blaxter et al. (1959) there would be little change in evaporative loss over this small range of temperature and their results show little increase in water intake from $8^{\circ}$ to $18^{\circ}$. In general the warmer weeks occurred at the beginning and end of the experiment, at times when the day length was longer 
than in the middle period of the experiment. The dry-matter intake of the ewes tended to be related to day length (Gordon, 1964) which meant that, at the time when the environmental temperature was colder, the dry-matter intake was less than the mean for the experiment and thus the fasting water requirement made up a greater proportion of the total requirement. The magnitude of this effect was, however, considerably less than that required to explain the steep slope of Fig. 2.

In the 3 weeks when environmental temperature was below $x^{\circ}$ the water intake was much greater than would have been predicted from equation (4). Winchester \& Morris (1956) and MacDonald \& Bell (I958) made similar observations with cattle. It is likely that the critical temperature of unshorn sheep is in the region of $0^{\circ}$ (Blaxter et al. 1959). Below this temperature, therefore, the ewe must increase her heat production in order to maintain her body temperature. This involves an increase in the metabolic activity of the body and therefore a stimulation of kidney function involving a greater loss of water in the urine.

The water intakes of non-pregnant ewes in these experiments are higher than those obtained by Blaxter et al. (1959) who fed dried grass to closely clipped wethers maintained at an environmental temperature of $8^{\circ}$; the mean water intake was $1 \cdot 4 \mathrm{~kg} /$ $\mathrm{kg}$ dry-matter intake. The fact that our ewes were carrying several months' growth of wool means that they would be less well able to lose heat from the skin and would therefore lose more heat from the respiratory tract. This involves greater vaporization of water and would thus increase the water requirements of the ewes. The water intakes in these experiments are also higher than those given by the Agricultural Research Council $(1965)$ for non-pregnant, non-lactating ewes at temperatures below $15^{\circ}$.

The effect of advancing pregnancy on water intake is clearly shown in Fig. 3. This is similar to the effect found by Head (1953) using values for twin-bearing Cheviot ewes at a constant level of nutrition. The Agricultural Research Council (1965) have used the results of Head in suggesting that the requirements of ewes in the $3^{\text {rd }} 4^{\text {th }}$ and 5 th months of pregnancy are $\mathrm{I} \cdot 5, \mathrm{I} \cdot 8$ and $2 \cdot 2$ times the requirements of similar but non-pregnant ewes. Table 3 shows that similar results were obtained for the twinbearing ewes in Expt 5 , but that ewes carrying only one lamb needed much less water than those carrying twins. Table 2 indicates that ewes with triplet foetuses might require an even greater allowance of water than those with twins. The Agricultural Research Council figures for the water requirements of pregnant ewes could be modified according to the expected lambing percentage.

Whereas the progress of pregnancy from Io to 19 weeks in the ewes fed on hay in Expt 3 was accompanied by a steady increase in total water intake per unit dry-matter intake (Fig. 3), the fluctuations in the water intake of the silage-fed ewes need some explanation. In the roth and I th weeks of pregnancy, silage alone was fed. As this had a dry matter percentage of 21 and as little free water was drunk, the ratio of water to dry-matter intake was close to $79: 21$, or 3.8 . In the i2th week concentrate feeding was introduced and increased in the $13^{\text {th }}$ week, but this was not accompanied by a marked increase in the intake of free water. In the I 4 th week, however, water intake increased and continued to do so until the end of the experiment. This was accompanied by a 
steady decrease in dry-matter intake which accentuated the slope of the curve in Fig. 3 for total water intake/dry-matter intake.

It would appear, therefore, that water intake is stimulated by pregnancy after the I4th week. This conclusion is confirmed by the results of Expt 5 (Fig. 3) in which the water intake was similar for pregnant and non-pregnant ewes until the $14^{\text {th }}$ week of pregnancy.

Despite the differences in water intake of ewes with different litter sizes as shown in the lower part of Fig. 3 and in Tables 2 and 3 , estimated foetal weight accounts for little of the variation in water intake per unit dry-matter intake (equations (5), (6) and (7)). In addition to the effect of pregnancy there are large differences between otherwise similar ewes which may be related to genetic differences in kidney function associated with, for example, erythrocyte potassium content (Evans, I957).

The increase in water intake with advancing pregnancy cannot be accounted for by the water content of the foetuses and foetal fluids at term which would amount to about $8 \mathrm{~kg}$ in the Specklefaced Welsh ewe carrying twins. The increment in water intake of such a ewe during the last 3 months of pregnancy above that of a nonpregnant ewe would on average be $120 \mathrm{~kg}$. Part of this increment would probably be accounted for by an increase in vaporization caused by the extra heat produced in pregnancy. Brockway, McDonald \& Pullar ( 1963 ) measured the heat production of non-pregnant ewes and of ewes throughout the course of pregnancy, both fed at the same level. The extra heat produced during pregnancy was $400 \mathrm{Mcal}$ and, although they did not investigate the partition of the loss of this heat, some of it would be lost by an increase in vaporization.

Increased heat production in pregnancy is a result of the increased metabolic activity of the body. This will involve a higher production of waste materials than in the non-pregnant state and thus a larger volume of urine, which increases until parturition (Forbes, unpublished observation). Both of these factors will contribute to the increase in water requirements during the last third of pregnancy. Whether they are sufficient to account for the whole of the increase cannot be deduced from the results of the present experiments because no attempt was made to measure the amounts of water lost by the various routes.

The fact that the water requirements of heavily pregnant ewes are greatly in excess of those of non-pregnant ewes is of particular practical importance. A failure to meet these increased water requirements, on the part of the shepherd, might depress feed intake (Gordon, I965). Such a depression in dry-matter intake would predispose heavily pregnant ewes to pregnancy toxaemia.

For the first 4 weeks of lactation total water intake per unit dry-matter intake was much higher than would be met by the Agricultural Research Council (1965) estimate that lactating ewes need $50 \%$ more water than dry ewes. If the water content of the milk is subtracted from the total water intake of the lactating ewes and the result then divided by dry-matter intake (Table 4), the result is still higher than the total water intake per unit dry-matter intake of the non-pregnant ewes. The difference may be due to the higher metabolic rate of the lactating ewe and the greater need for water in vaporization and excretion. 
From the $5^{\text {th }}$ to the $7^{\text {th }}$ week of lactation, however, the discrepancy between the water intake of lactating ewes minus the water in the milk, and the estimated water intake of dry ewes was not great. When total water intake can be related to dry-matter intake plus an allowance for milk yield, then the total water intake per unit dry-matter intake will depend on the milk yield; the higher the milk yield at a given dry-matter intake, the greater the total water intake per unit dry-matter intake.

The results obtained in these experiments agree in general with those obtained elsewhere. The effect of litter size on water intake in pregnancy has not, so far as is known, been shown before and may be of use to supplement the work of Head (r953). The results presented here are apparently the first report on the water intake of lactating ewes and they are not clear enough to form the basis of a general recommendation.

Thanks are due to Messrs M. Appleton and F. Cass for technical assistance, to Mr R. Lax for the chemical analyses of the feeds, and to Mr T. G. Boaz and Mr J. Hodgson for helpful discussion during the preparation of this paper.

\section{REFERENCES}

Agricultural Research Council (1965). The Nutrient Requirements of Farm Livestock. No. 2. Ruminants, p. 7. London: Agricultural Research Council.

Blaxter, K. L., Graham, N. McC., Wainman, F. W. \& Armstrong, D. G. (1959). F. agric. Sci., Camb. 52, 25.

Bott, E., Denton, D. A. \& Weller, S. (1965). F. Physiol., Lond. 176, 323.

Brockway, J. M., McDonald, J. D. \& Pullar, J. D. (xg63). F. Physiol., Lond. x67, 3 r8.

Calder, F. W., Nicholson, J. W. G. \& Cunningham, H. M. (1964). Can. F. Anim. Sci. 44, 266.

Cizek, L. J. (1959). Am. F. Physiol. r97, 342.

Evans, J. V. (1957). Nature, Lond. 180, 756.

Gordon, J. G. (1964). Nature, Lond. 204, 798.

Gordon, J. G. (1965). F. agric. Sci., Camb. 64, 31 .

Harris, C. E. \& Wilson, R. F. (1964). Exps Prog. Grassld Res. Inst. 16, 63.

Head, M. J. (1953). F. agric. Sci., Camb. 43, 2 r4.

Leitch, I. \& Thomson, J. S. (1944). Nutr. Abstr. Rev. 14, 197.

MacDonald, M. A. \& Bell, J. M. (1958). Can. F. Anim. Sci. 38, 23.

Snedecor, G. W. (1956). Statistical Methods. Ames, Iowa: Iowa State College Press.

Sykes, J. F. (1955). The Yearbook of Agriculture: Water, p. 14. Washington, D.C.: United States Department of Agriculture.

Wilson, A. D. (I966). Aust. $¥$. agric. Res, 17, 503 .

Winchester, C. F. \& Morris, M. J. (1956). F. Anim. Sci. 15, 722. 